\title{
Pandangan Muslim Terhadap Sektor Fitness and Mind Body: Literature Study Approach Model
}

\author{
Sunarmo $^{\left.1^{*}\right)}$, Hanny Nurlatifah ${ }^{2),}$ Bambang Eko Samiono $^{3}$, Ani Asriyah ${ }^{4}$, Sabda Ilahi Rizki ${ }^{5}$, Nadiyah \\ Afifah $^{6}$ \\ ${ }^{1,2,3,5,6}$ Fakultas Ekonomi dan Bisnis, Universitas Al Azhar Indonesia \\ ${ }^{4}$ Fakultas Ekonomi dan Bisnis, Universitas Lampung \\ *Email Korespondensi : sunarmo@uai.ac.id
}

\begin{abstract}
Healthy lifestyle is an inseparable thing for Indonesian people today, including generation $X$ (baby boomers), $Y$ (millennial) and Z. Concern for health indirectly affects the growth of the health sector, especially the fitness and mind sub sector. The dominance of Muslims around 87\% in Indonesia is an interesting study for research because there are still not many studies on it. Literature research methods by collecting data and retrieving data from libraries, reading, taking notes, and processing research materials. The results of the research on the preferences of the Muslim community in Indonesia in choosing halal wellness, especially the fitness \& mind body sub-sector according to the provisions of the DSN-MUI Number 108 of 2016 concerning Guidelines for Implementation of Tourism based on Sharia Principles such as room facilities, availability of places for equality, gender separation, dress code availability of halal food and drinks, etc.
\end{abstract}

Keywords: Halal, Muslim consumers, literature study approach., fitness \& mind body subsectors.

Saran sitasi: Sunarmo., Nurlatifah, H., Samiono, B. E., Asriyah, A., Rizki, S. I., \& Afifah, N. (2021). Pandangan Muslim Terhadap Sektor Fitness and Mind Body: Literature Study Approach Model. Jurnal Ilmiah Ekonomi Islam, 7(01), 451-459. doi: http://dx.doi.org/10.29040/jiei.v7i1.2200

DOI: http://dx.doi.org/10.29040/jiei.v7i1.2200

\section{PENDAHULUAN}

Masyarakat urban atau perkotaan selalu disibukkan dengan rutinitas sehari-hari utamanya bekerja baik di sektor formal maupun informal. Hal tersebut tentu melelahkan bahkan secara tidak langsung dapat mengubah gaya hidup mereka. Selain gaya hidup, beban kerja yang menumpuk berpengaruh kepada gangguan fisiologis, psikologis dan perilaku yang berujung stres seperti darah tinggi, gangguan lambung, sulit mengambil keputusan, serangan jantung, ketidakpuasan kerja, dan mengundurkan diri dari tempat kerja (Robbins, 2006)

Oleh karena itu akhir pekan, waktu luang atau libur panjang menjadi waktu yang tepat untuk menghilangkan stres. Salah satu cara yang dapat dilakukan yaitu mengunjungi tempat kebugaran dan kesehatan (wellness tourism). Wisata wellness adalah salah satu bagian dari industri ekonomi wellness (wellness economy industry). Definisi wellness tourism menurut Global Wellness Institute (2017) adalah suatu perjalanan wisata seseorang yang berhubungan dengan mengejar ketenangan dan meremajakan tubuh. Wellness tourism merupakan suatu fenomena bepergian ke destinasi wisata dengan tujuan untuk memperoleh jasa dan pengalaman untuk meremajakan tubuh (Chen et al., 2008).

Tabel 1. Perkembangan Industri Wellness 2015 dan 2017

\begin{tabular}{|c|c|c|}
\hline \multirow[t]{2}{*}{ No Sub sektor Industry } & $\begin{array}{l}\text { Ukuran Pasar } \\
\text { (US\$ milyar) }\end{array}$ & \multirow{2}{*}{$\begin{array}{l}\text { Rata - rata } \\
\text { Pertumbuhan } \\
\text { tahunan }(\%)\end{array}$} \\
\hline & 2015 & \\
\hline $\begin{array}{l}1 \text { Personal care, beauty, } \\
\text { \& Anti Aging }\end{array}$ & , \$999.0 $1,082.9$ & 4.1 \\
\hline $\begin{array}{l}2 \text { Healthy eating, } \\
\text { nutrition \& Weight } \\
\text { Loss }\end{array}$ & $\$ \$ 647.8 \quad \$ 702.1$ & 4.1 \\
\hline 3 Wellness Tourism & $\$ 563.2 \quad \$ 639.4$ & 6.5 \\
\hline 4 Fitness \& Mind-Body & $\$ 542.0 \quad \$ 595.4$ & 4.8 \\
\hline
\end{tabular}




\section{Jurnal Ilmiah Ekonomi Islam, 7(01), 2021, 452}

\begin{tabular}{|c|c|c|}
\hline \multirow[t]{2}{*}{ No Sub sektor Industry } & $\begin{array}{l}\text { Ukuran Pasar } \\
\text { (US\$ milyar) }\end{array}$ & \multirow[t]{2}{*}{$\begin{array}{l}\text { Rata - rata } \\
\text { Pertumbuhan } \\
\text { tahunan }(\%)\end{array}$} \\
\hline & \begin{tabular}{|ll}
2015 & 2017
\end{tabular} & \\
\hline $\begin{array}{l}\text { Preventive \& } \\
\text { Personalized Medicine } \\
\text { and Public Health }\end{array}$ & $\$ 534.3 \quad \$ 574.8$ & 3.7 \\
\hline $\begin{array}{ll}6 & \text { Traditional \& } \\
& \text { Complementary } \\
& \text { Medicine** }\end{array}$ & $\begin{array}{l}* * \$ 199 . * * \$ 359 . \\
0\end{array}$ & $* *$ \\
\hline $\begin{array}{l}\text { Wellness Real } \\
\text { Estate } * * *\end{array}$ & $\$ 118.6 \quad \$ 134.3$ & 6.4 \\
\hline $\begin{array}{l}\text { Spa Economy (Spa } \\
\text { Facilities) }\end{array}$ & $\begin{array}{ll}98.6 & \$ 118.8 \\
(\$ 77.6) & (\$ 93.6\end{array}$ & $\begin{array}{l}* * * * 9.8 \% \\
* * * *(9.9 \%)\end{array}$ \\
\hline $\begin{array}{l}9 \text { Thermal/Mineral } \\
\text { Springs }\end{array}$ & $\$ 51.0$ & 4.9 \\
\hline 10 Workplace Wellness & $\$ 43.3$ & 4.8 \\
\hline $\begin{array}{l}\text { Wellness Economy } \\
\text { total }\end{array}$ & $\begin{array}{l}* \$ 3,724 . * \$ 4,220 \\
4\end{array}$ & 6.4 \\
\hline
\end{tabular}

Pada tabel 1. terlihat secara global industri wellness pada tahun 2017 menyumbang \$4,220.2 triliun. Sub sektor penyumbang terbesar yaitu Personal care, beauty, \& Anti Aging, Healthy eating, nutrition \& Weight Loss, Wellness Tourism, dan Fitness \& Mind-Body. Secara rata - rata tahunan sub sektor fitness \& mind body mengalami pertumbuhan $4,8 \%$, artinya bahwa sub sektor tersebut sudah menjadi bagian gaya hidup masyarakat dalam meningkatkan kesehatan dan kebugaran tubuh.

Peningkatan pertumbuhan sub sektor fitness \& mind body secara global salah satunya ditopang oleh Indonesia. Walaupun berdasarkan data menunjukkan bahwa penetrasi fitnes di Indonesia masih tergolong rendah dengan total penetrasi pasar pada kisaran 0,12 persen tiap tahunnya. Diketahui bahwa per 2018 pendapatan sub sektor fitness \& mind body sebesar USD 188 juta dengan 320.000 konsumen dan 1.700 klub kebugaran. Akan tetapi, diprediksi pada 2030 pendapatan sub sektor ini meningkat menjadi US $\$ 8,7$ mliar, hal ini dipengaruhi oleh gaya hidup milenial yang cenderung memikirkan kesehatan (Merdeka, 2008). Selain itu, data lain mengatakan bahwa gaya hidup sehat masyarakat Indonesia mulai meningkat baik dari generasi $\mathrm{Z}, \mathrm{Y}$ dan $\mathrm{X}$. Hal tersebut dapat dilihat dari data yang dirilis platform shopee (2019) yang menyebutkan bahwa sepanjang 2017-2019 terjadi peningkatan pembelian produk dan alat kesehatan sebanyak 3 sampai empat kali lipat dibandingkan periode sebelumnya.

Latar belakang tersebut mendororong peneliti untuk meneliti tentang perilaku masyarakat Muslim dalam memilih wellness industry khususnya tempat fitness \& mind body. Alasan Muslim menjadi kajian penelitian yaitu berdasarkan BPS (2010) dan Global Islamic Economy Report (2019) sebanyak 237.641.326 jiwa atau sekitar $87 \%$ penduduk Indonesia beragama Islam. Selain itu objek masyarakat muslim dipilih karena mempunyai kebutuhan berbeda. Selain itu, penelitian-penelitian terdahulu tentang perilaku konsumen muslim lebih banyak tentang produk halal seperti makanan, minuman dan barang olahan yang bersertifikat halal dibandingkan perilaku Muslim terhadap jasa layanan yang memenuhi kategori halal. Penelitian ini bertujuan untuk mengetahui dan menganalisis perspektif Muslim terhadap sub sektor fitness \& mind body dengan pendekatan studi literatur.

\section{TINJAUAN PUSTAKA}

\section{Studi Literatur}

Metode literatur adalah salah satu metode pengumpulan data yang digunakan dalam metodologi penelitian sosial untuk menelusuri data historis (Bungin, 2008). Sedangkan Literatur merupakan catatan peristiwa yang sudah berlalu yang berbentuk tulisan, gambar, atau karya-karya monumental dari seseorang (Sugiono, 2005). Isi literatur dapat diklasifikasikan menjadi dua. Pertama sumber primer (primary source) dan kedua sumber sekunder (secondary source). Sumber primer adalah karangan asli yang ditulis oleh seorang yang melihat, mengalami, atau mengerjakan sendiri.

Bahan Literatur semacam ini dapat berupa buku harian (autobiography), tesis, disertasi, laporan penelitian, dan hasil wawancara. Selain itu sumber primer dapat berupa laporan pandangan mata suatu pertandingan, statistik sensus penduduk dan lain sebagainya. Sedangkan, sumber sekunder (secondary source) adalah tulisan tentang penelitian orang lain, tinjauan, ringkasan, kritikan, dan tulisan-tulisan serupa mengenai hal-hal yang tidak langsung disaksikan atau dialami sendiri oleh penulis. Bahan Literatur sekunder terdapat di ensiklopedi, kamus, buku pegangan, abstrak, indeks, dan textbooks.

\section{Gym Center}

Usaha gym/center/sport centre merupakan sub jenis dari jenis usaha gelanggang rekreasi olahraga yang termasuk Bidang Usaha Penyelenggaraan Kegiatan Hiburan dan Rekreasi menurut Peraturan 


\section{Jurnal Ilmiah Ekonomi Islam, 7(01), 2021, 453}

Gubernur Provinsi DKI Jakarta Nomor 18 Tahun 2018 tentang Penyelenggaraan Usaha Pariwisata dan Peraturan Gubernur Provinsi DKI Jakarta Nomor 18 Tahun 2018 tentang Penyelenggaraan Usaha Pariwisata. Fitness Center ialah salah satu produk dari industri yang menghasilkan jasa. Jasa yaitu setiap tindakan atau kinerja yang ditawarkan oleh satu pihak ke pihak lain yang secara prinsip tidak berwujud dan tidak mengakibatkan perpindahan kepemilikan. Produksi jasa sanggup terikat atau tidak terikat pada suatu produksi fisik (Kotler \& Keller, 2006).

\section{Fitness and Mind Body}

Fitness \& mind body adalah salah satu sub sektor industri wellness dan merupakan sub sektor yag memiliki pertumbuhan terbesar kedua dari tahun 2013-2015 yaitu sebesar 10,2\%. Golongan fitness \& mind body yaitu gym dan klub kesehatan; pelatihan pribadi; yoga, Pilates, Tai Chi, seni bela diri, dan praktik mind body lainnya seperti pakaian fitnes dan peralatan/perangkat fitnes (Wellness Now a $\$ 4.2$ Trillion Global Industry - Global Wellness Institute, n.d.).

Praktik mind body dalam bidang medis dan psikologis telah menghasilkan konseptualisasi kesehatan dan kesejahteraan yang menyeluruh. Model Keterampilan Mental Kardinal dari psikologi olahraga dapat membantu dengan adanya integrasi kesejahteraan aspek fisik dan mental di arena olahraga dan kebugaran. Konsep ini berfokus pada keterampilan yang ditujukan untuk peningkatan kinerja yaitu relaksasi, konsentrasi, self-talk, imagery, dan rutinitas. Hubungan mind body ini memiliki keterkaitan antara proses psikologis dan proses fisiologis, dapat dikonseptualisasikan sebagai dua arah, menunjukkan bahwa pikiran dan perasaan mempengaruhi apa yang terjadi di dalam tubuh, menciptakan perubahan fisik yang mempengaruhi kesehatan. Sebaliknya, penyakit fisik memengaruhi risiko penyakit psikologis (Beauchemin et al., 2015)

\section{Penelitian Terdahulu}

Komitmen beragama memperkuat pengaruh variabel produk berlabel Halal pada kepuasan pelanggan. Dalam kelompok pelanggan dengan komitmen agama yang tinggi, itu menemukan bahwa ketersediaan produk berlabel halal mendorong tingkat kepuasan menjadi semakin tinggi, artinya semakin tinggi komitmen beragama seseorang maka semakin tinggi pula kepedulian akan pentingnya memastikan bahwa kegiatan konsumsi dilakukan menurut hukum
Islam, terutama terkait dengan hukum halal-haram (Sobari et al., 2019)

Pendorong utama wanita Muslim berolahraga di Gym dan pusat kebugaran (fitness center) adalah aspek sosial dari latihan dan pilihan dengan pendekatan holistik dan mempertimbangkan fasilitas ruang yang sesuai dengan budaya wanita muslim (Summers et al., 2018). Fitnes center khusus wanita yang memiliki fasilitas olahraga yang beragam, adanya mushola bagi muslim, instruktur yang kompeten, lokasi yang strategis dekat dengan Bank, kedai kopi dan masjid (Mohamed et al., 2019).

Adanya budaya Iran dan keyakinan agama wanita Muslim serta karena adanya pembatasan aktivitas fisik untuk wanita di setiap tempat. Situs web pendidikan tentang wanita, aktivitas fisik dan manfaat olahraga teratur di situs web. Tempat yang dikhususkan untuk aktivitas fisik dengan foto dan karakteristiknya, seperti taman khusus wanita, sesi khusus wanita, pusat kebugaran khusus wanita dan kompleks olahraga (Peyman et al., 2020).

Penyediaan lingkungan halal ditunjukkan dengan fasilitas ramah keluarga dan ketersediaan kamar bebas rokok, maka penyediaan ibadah dibuktikan dengan ketersediaan sajadah dan arah kiblat di dalam kamar, jam yang berbeda atau terpisah untuk fitnes center (Muharam \& Asutay, 2019).

\section{METODE PENELITIAN}

Penelitian ini menggunakan metode studi literatur, metode literatur adalah salah satu metode pengumpulan data yang digunakan dalam metodologi penelitian sosial untuk menelusuri data histories (Bungin, 2008). Sedangkanl iteratur merupakan catatan peristiwa yang sudah berlalu yang berbentuk tulisan, gambar, atau karya-karya monumental dari seseorang (Sugiono, 2005). Bahan Literatur di peroleh dari laman database hasil penelitian Proquest, Emerald Insight, dan Google Scholar yang berisi tesis, disertasi, laporan penelitian berupa jurnal.

Data yang digunakan adalah data sekunder. Data sekunder yang berasal publikasi pihak ketiga yaitu Laporan Global Wellness Economy Monitor 2018, laporan Badan Pusat Statistik (BPS), penelitianpenelitian ilmiah terdahulu bersumber dari database Proquest, Emerald Insight, dan Google Scholar, Fatwa Majelis Ulama Indonesia No.108/DSNMUI/X/2016 tentang Pedoman Penyelenggaraan Pariwisata Berdasarkan Prinsip Syariah dan artikel 
relevan lainnya. Alur penelitian seperti pada gambar dibawah ini:

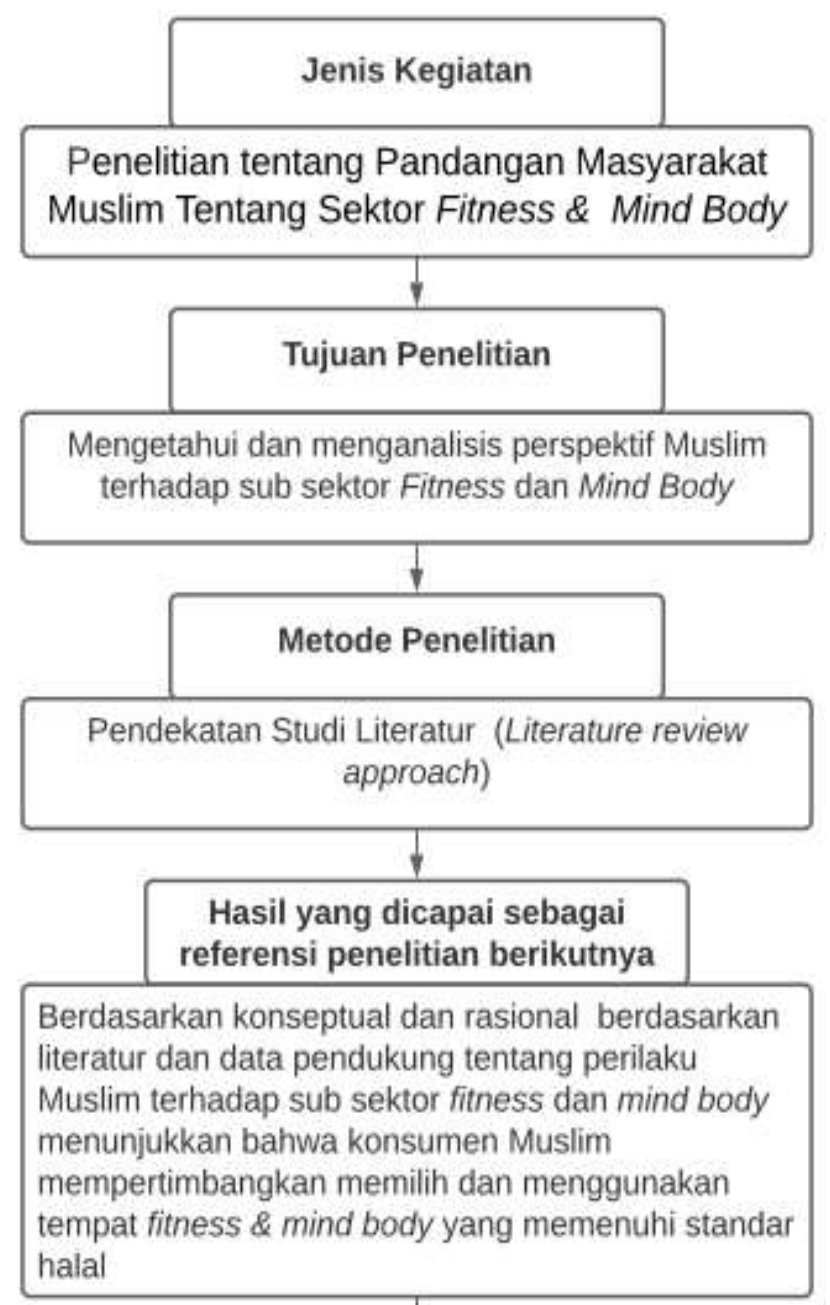

Gambar 1. Alur penelitian

\section{HASIL DAN PEMBAHASAN}

\section{Perkembangan dan Tren Fitness \& Mind Body}

Pertumbuhan jumlah konsumen Muslim dunia dan perkembangan wellness industry, merupakan peluang bagi dunia bisnis untuk lebih banyak berkarya pada sektor halal wellness industry. Indonesia sebagai ekonomi dengan Muslim potensi pasar yang mencakup 12,7 persen umat Islam dunia. Kebutuhan barang dan jasa dari sektor industri kebugaran (wellness industry) pun tak luput dari tuntutan halal mengingat banyaknya titik kritis bahan baku halal dalam produksi barang dan kesesuaian Syariah dalam operasi penyediaan layanan wellness industy (Sobari et al., 2019). Perkembangan wellness industry terutama sub sektor fitness dan mind body dapat ditampilkan oleh tabel berikut:
Tabel 2. Perkembangan sub sektor Fitness dan Mind-Body

\begin{tabular}{cc}
\hline Tahun & Ukuran Pasar (US\$ milyar) \\
\hline 2013 & 446.4 \\
\hline 2015 & 542.0 \\
\hline 2017 & 595.4 \\
\hline 2018 & 595.4 \\
\hline
\end{tabular}

Sumber : Laporan Global Wellness Economy Monitor, 2013-2018

Konseptualisasi holistik kesehatan dan kebugaran ini telah memengaruhi tren industri seperti adanya pelatihan profesional kebugaran dan yang terpenting, harapan konsumen. Pergeseran ini dibuktikan dengan pelatihan lanjutan dan sertifikasi yang melampaui arena fisik tradisional seperti adanya Pelatih Kesehatan, dan Gaya Hidup dan Konsultan Manajemen Berat Badan (Beauchemin et al., 2015)

Kesadaran akan gaya hidup sehat masyarakat mengalami peningkatan, hal ini ditunjukkan dengan meningkatnya jumlah sub sektor fitness \& mind body dari tahun 2013-2018, jumlah ini salah satunya di topang oleh Indonesia. Dikutip dari laman lifestyle okezone.com, survei perusahaan asuransi dan lembaga penelitian menunjukkan bahwa $73 \%$ masyarakat Indonesia menempatkan kesehatan pribadi sebagai isu nomor satu dalam kehidupannya. Jumlah ini meningkat 19\% dari indeks yang sama pada tahun 2017.

Peningkatan akan kesadaran hidup sehat masyarakat tidak terlepas dari populasi masyarakat Indonesia yang di dominasi oleh masyarakat muslim yang terdiri dari generasi X, Y, dan Z. Saat ini gaya hidup halal, terutama dalam hal mengonsumsi produk halal, tidak hanya menjadi kebiasaan dan konsumsi penduduk muslim, namun sudah mulai menjadi gaya hidup yang dianggap sehat dan baik bagi kesehatan penduduk dunia termasuk di negara-negara yang memiliki jumlah penduduk muslim yang relatif sedikit, tidak hanya mengenai produk barang halal saja kini mengkonsumsi jasa halal pun menjadi gaya hidup baru masyarakat muslim.

Meningkatnya gaya hidup halal mendorong adanya wisata halal (halal tourism) dimana masyarakat muslim memperhatikan produk seperti makanan halal, pakaian, tempat ibadah, dan lingkungan wisata dengan suasana ramah muslim. Dalam konteks wisata halal basis yang digunakan adalah syariah Islam dalam pelayanan dan produk 
wisata yang tidak hanya di negara Islam, tetapi juga negara non-Islam. Wisata halal bisa mencakup halal hotel, halal restaurant, halal resort, halal trip, dan halal kesehatan dan kebugaran. Gaya hidup yang halal berarti pula gaya hidup yang bersih dan sehat. Wisata halal yang sedang digemari masyarakat tidak hanya tentang hal tersebut saja, salah satunya rekreasi olahraga yang menyehatkan seperti mengunjungi pusat kebugaran (fitness center) yang berbasis halal. Hal ini merupakan sub sektor dalam industri wellness yaitu fitness and mind body.

Di Indonesia sendiri terdapat beberapa produk halal di bidang jasa seperti hotel syariah, pusat kebugaran (fitness center) dan kesehatan. Hotel syariah yang mendapatkan sertifikasi halal dari DSNMUI yaitu Syariah Hotel Solo, Hotel Sofyan Hotel Cut Meutia, Sofyan Hotel Soepomo, Permata Hotel Convention Center, Grand Permata Hati dan lain-lain. Sofyan Hotel Soepomo dan Syariah Hotel Solo memiliki fasilitas fitnes center yang terpisah antara laki-laki dan perempuan (Bastaman, 2019). Salah satu tempat fitness and mi nd body yang berbasis syariah yaitu S Fitness Center khusus perempuan Muslim di Kota Bandung, meskipun memiliki pelayanan yang sesuai dengan kriteria syariah seperti yang ditetapkan oleh DSN-MUI, tempat fitnes ini masih belum memiliki sertifikasi halal. Label halal yang dikeluarkan oleh MUI merupakan salah satu variabel yang menentukkan preferensi masyarakat muslim menetukkan tempat fitness \& mind body (Bauty, 2020).
Penelitian-Penelitian terdahulu tentang fitness \& main body berbasis Syariah

Penelitian terdahulu berdasarkan studi literatur dari database google scholar. Pencarian pada google scholar dengan kata kunci "Fitness \& mind body for Muslim". Dari kata kunci tersebut ditemukan sekitar 28.100 hasil dalam 0,08 detik. Kemudian pencarian dipersempit 5 tahun terakhir (2015 - 2020), hasilnya ditemukan sebanyak 11.300 artikel. Selanjutnya peneliti menambahkan kata kunci "disertasi", hasilnya ditemukan sebanyak 5.120 artikel, tapi hanya 3 artikel yang relevan.

Tidak hanya melalui google scholar studi literatur juga dilakukan dengan cara mencari proquest.com dan Emerald Insight, peneliti melakukan pencarian dengan kata kunci "fitness \& mind body for muslim". Berdasarkan pencarian tersebut diperoleh hasil 55.996 artikel terdiri dari jurnal, buku, audio \& video, dan lainnya. Peneliti memfilter artikel yang berasal dari jurnal dan konferensi. Hasil filter menemukan sebanyak 947 artikel, lalu memfilter kembali berdasarkan artikel 5 tahun terakhir, hasilnya menunjukkan 326 artikel. Dari 326 artikel jurnal dan prosiding, peneliti melakukan identifikasi terhadap topik yang relevan hasilnya hanya 4 jurnal yang cukup sesuai digunakan sebagai literatur. Berikut merupakan hasil ringkasan penelitian terdahulu bersumber dari database google scholar, proquest dan Emerald insight.

Tabel 3. Hasil Penelitian Terdahulu

\begin{tabular}{|c|c|c|}
\hline No Peneliti/Judul/Tahun & Variabel dan Metode Penelitian & Hasil Penelitian \\
\hline $\begin{array}{l}\text { J. Summers, R. Hassan, } \\
\text { Derek Ong, dan M. } \\
\text { Hossain Australian } \\
\text { Muslim women and } \\
\text { fitness choices - myths } \\
\text { debunked } \\
(2018)\end{array}$ & $\begin{array}{l}\text { Pendekatan Kualitatif } \\
\text { Variabel: } \\
\text { 1. Segmentasi berbasis keyakinan } \\
\text { 2. Motivasi untuk berolahraga } \\
\text { 3. Citra tubuh } \\
\text { 4. Religiusitas }\end{array}$ & $\begin{array}{l}\text { Pendorong utama wanita Muslim } \\
\text { berolahraga di Gym dan pusat } \\
\text { kebugaran (fitnes center) adalah aspek } \\
\text { sosial dari latihan dan pilihan dengan } \\
\text { pendekatan holistik dan } \\
\text { mempertimbangkan fasilitas ruang yang } \\
\text { sesuai dengan budaya wanita muslim. }\end{array}$ \\
\hline $\begin{array}{l}\text { 2. Peyman et. Al } \\
\text { Digital Media-based } \\
\text { Health Intervention on } \\
\text { the promotion of } \\
\text { Women's physical } \\
\text { activity: a quasi- } \\
\text { experimental study } \\
\text { (2018) }\end{array}$ & $\begin{array}{l}\text { Pendekatan Kuasi Eksperimental } \\
\text { Variabel: } \\
\text { 1. Pengetahuan wanita, } \\
\text { 2. Sikap } \\
\text { 3. Aktivitas fisik di antara kelompok } \\
\text { kontrol dan kasus }\end{array}$ & $\begin{array}{l}\text { Situs web pendidikan tentang wanita, } \\
\text { aktivitas fisik dan manfaat olahraga } \\
\text { teratur di situs web. Tempat yang } \\
\text { dikhususkan untuk aktivitas fisik dengan } \\
\text { foto dan karakteristiknya, seperti taman } \\
\text { khusus wanita, sesi khusus wanita, pusat } \\
\text { kebugaran khusus wanita dan kompleks } \\
\text { olahraga. Karena budaya Iran dan } \\
\text { keyakinan agama wanita Muslim dan }\end{array}$ \\
\hline
\end{tabular}


oleh karena adanya pembatasan aktivitas fisik untuk wanita di setiap tempat.

\begin{tabular}{ll}
\hline Kristin Walseth & Pendekatan kualitatif dengan \\
Sport within Muslim & pemetaan dan interview \\
organizations in & Variabel : \\
Norway: ethnic & Modal sosial \\
segregated activities as & ( kepercayaan, dukungan timbal balik, \\
$\begin{array}{l}\text { arenafor integration } \\
\text { (2016) }\end{array}$ & norma kerja sama, keterlibatan sipil, \\
& dan jaringan sosial)
\end{tabular}

Organisasi Muslim menawarkan berbagai kegiatan olahraga dari karate, bulu tangkis hingga fitnes, renang dan kegiatan rekreasi untuk orang tua. Organisasi ini dibangun berdasarkan pedoman syariah yaitu menyangkut non pencampuran gender, kode berpakaian. Tujuan Organisasi muslim menawarkan Olahraga adalah mengembangkan modal sosial dan integrasi.

\begin{tabular}{lll}
\hline 4ameera M. Al Zaidi & Pendekatan Kualitatif \\
dan Syed Z. Ahmad & Variabel: \\
Tone fitness ladies' & 1. Struktur pasar \\
studio: $\quad$ market & 2. Jangka waktu berlangganan \\
segmentation or market & 3. Wilayah \\
mix? & 4. Aliran pendapatan \\
$(2019)$ & 4. Lanskap kompetitif
\end{tabular}

Fitnes center khusus wanita yang memiliki fasilitas olahraga yang beragam, adanya mushola bagi muslim, instruktur yang kompeten, lokasi yang strategis dekat dengan Bank, kedai kopi dan masjid.

\begin{tabular}{|c|c|}
\hline $\begin{array}{l}\text { 5. Muharam dan Asutay } \\
\text { Online Disclosure } \\
\text { Practices of Halal- } \\
\text { Friendly Hotels } \\
\text { (2018) }\end{array}$ & $\begin{array}{l}\text { Pendekatan deduktif melalui literatur } \\
\text { Variabel: } \\
\text { (1) artikulasi identitas Islam (empat } \\
\text { sub-kategori); } \\
\text { (2) praktik terbaik ramah halal (empat } \\
\text { sub-kategori); } \\
\text { (3) penyediaan lingkungan halal } \\
\text { (delapan sub-kategori); dan } \\
\text { (4) ketentuan ibadah (tujuh sub- } \\
\text { kategori }\end{array}$ \\
\hline
\end{tabular}

6. Bastaman

Pendekatan kualitatif

melalui wawancara

Exploratory Analysis of

Halal Hotel Services:

Variabel:

Based On Practices of

Halal Hotels In Three

kualitas manajemen dari perspektif Islam, makanan dan minuman, fasilitas, keuangan, asuransi, paket perjalanan, transportasi / maskapai Countries

(2019) penerbangan, dan aktivitas terkait perjalanan / akomodasi lainnya.

Penyediaan lingkungan halal ditunjukkan dengan fasilitas ramah keluarga dan ketersediaan kamar bebas rokok, maka penyediaan ibadah dibuktikan dengan ketersediaan sajadah dan arah kiblat di dalam kamar, jam yang berbeda atau terpisah untuk fitnes center.

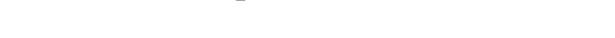
merupakan prasyarat atau persyaratan dasar. Namun harus didukung dengan fasilitas yang lebih baik dan juga harus digabungkan dengan customer service dan standar pelayanan yang tinggi. Prinsip dasar kualitas pelayanan yang tinggi seperti kode berpakaian staf dan tamu, cara pembayaran, asuransi dan penggunaan fasilitas perbankan. Customer service diantaranya fitnes center pria dan wanita yang terpisah,semua makanan halal dan minuman non alkohol, kolam renang terpisah antara pria dan wanita.

Sumber : Google scholar, proquest dan emerald insight.

Berdasarkan studi literatur (tabel 1) yang telah dilakukan maka di temukan hasil bahwa pereferensi masyarakat Muslim dalam memilih tempat fitness \& mind body yaitu aspek sosial dengan pendekatan holistik, fasilitas ruang, tersedianya tempat beribadah, pemisahan gender, kode berpakaian, lokasi yang strategis, instruktur yang kompeten, fasilitas olahraga yang beragam, prinsip dasar kualitas pelayanan yang tinggi seperti kode berpakaian staf dan tamu, cara pembayaran, asuransi dan penggunaan fasilitas perbankan, tersedia makanan halal dan minuman non alkohol serta budaya muslim. Aspek - aspek pada 
penelitian tersebut semua mengarah kepada fasilitas dan pelayanan yang berbasis Syariah. Nilai Syariah tersebut sesuai dengan Fatwa DSN-MUI Nomor 108 Tahun 2016 Tentang Pedoman Penyelenggaraan Pariwisata Berdasarkan Prinsip Syariah ketentuan kelima (hotel Syariah) dan keenam (spa, sauna dan massage). Pada ketentuan hotel Syariah dikatakan bahwa :

a. Hotel Syariah tidak boleh menyediakan fasilitas hiburan yang mengarah pada kemusyrikan, maksiat, pornografi, dan tindakan asusila

b. Menyediakan fasilitas, peralatan dan sarana yang memadai untuk pelaksanaan ibadah termasuk bersuci.

c. Hotel Syariah wajib memiiki pedoman dan/atau panduan mengenai prosedur pelayanan hotel yang sesuai Syariah.

Sementara itu ketentuan Syariah pada spa, sauna dan massage yang merupakan bagian dari mind body yaitu:

a. Terhindar dari pornografi dan pornoaksi

b. Terjaganya kehormatan wisatawan

c. Terapis laki - laki hanya boleh melakukan spa, sauna, dan massage kepada wisatawan laki - laki, dan wanita kepada wisatawan wanita

d. Tersedia sarana yang memudahkan untuk beribadah

Deskripsi layanan pada hotel Syariah dan mind body sebagaimana pada Fatwa MUI tentang pariwisata Syariah sesuai dengan hasil penelitian Vargo dan Lusch (2012), bahwa penyedia layanan harus berusaha memaksimalkan keterlibatan pelanggan dalam kinerja layanan karena pelanggan harus menjadi produsen bersama dari layanan yang diberikan. Oleh karena itu, penyedia jasa harus mengetahui siapa pelanggannya, dalam hal ini pelanggan jasa halal wellness, serta memahami kebutuhan dan preferensinya berdasarkan norma dan ajaran Islam (Vargo \& Lusch, 2012).

Menurut penelitian salah satu tempat fitness \& mind body khusus perempuan Muslim di kota Bandung bahwa meskipun memiliki pelayanan yang sesuai dengan kriteria syariah seperti pada Fatwa Majelis Ulama Indonesia (MUI) No.108/DSNMUI/X/2016 tentang Pedoman Penyelenggaraan Pariwisata Berdasarkan Prinsip Syaruiah, tempat fitnes ini masih belum memiliki sertifikasi halal. Label halal yang dikeluarkan oleh MUI merupakan salah satu variabel yang menentukkan preferensi masyarakat muslim menetukkan tempat fitness \& mind body (Bauty, 2020). Meningkatnya pengembangan resort Islami yang dicari oleh masyarakat Muslim diantaranya yaitu tersedianya fasilitas kebugaran (fitnes center) yang dipisahkan berdasarkan gender dan memiliki hiburan Islami (Henderson, 2009).

Berdasarkan data perkembangan sektor fitness \& mind body serta penelitian terdahulu dapat dikatakan bahwa nilai - nilai syariah merupakan aspek penting dalam memengaruhi Muslim melakukan latihan kebugaran. Penerapan nilai Syariah sesuai Fatwa Majelis Ulama Indonesia (MUI) diterapkan dalam bentuk fasilitas kebugaran, fasilitas pendukung yang Islami seperti terpisahnya tempat latihan kebugaran antara pria dan wanita, tersedianya kuliner halal, perbankan dan sistem pembayaran Syariah. Akan tetapi, muslim akan menjadi lebih tenang saat melakukan olahraga di tempat fitness \& mind body bersertifikat halal, sesuai penelitian (Bauty, 2020) Sertifikasi halal pada jasa fitness \& mind body belum diatur oleh pemerintah Indonesia, padahal potensi muslim di Indonesia sangat besar yaitu 235 juta jiwa penduduk dan sertifikasi halal mempunyai kedudukan yang sentral karena sudah menjadi regulasi peraturan perundang - undangan sehingga mampu memengaruhi masyarakat atau konsumen melakukan olahraga di tempat fitness \& mind body.

Undang - Undang Nomor 33 Tahun 2014 tentang Jaminan produk halal menyebutkan bahwa produk meliputi barang dan/atau jasa terkait dengan makanan, minuman, obat, kosmetik, produk kimiawi, produk biologi, dan produk rekayasa genetik serta barang gunaan yang dipakai, digunakan, atau dimanfaatkan oleh masyarakat. Kehalalan produk jasa berdasarkan UU Jaminan Produk halal hanya meliputi jasa penyembelihan hewan, jasa pengolahan, jasa penyimpanan, jasa penyajian, jasa pengemasan, dan jasa pendistribusian. Dapat disimpulkan bahwa produk jasa yang wajib bersertifikat halal merupakan jenis jasa yang berhubungan langsung dengan proses pembuatan produk barang (Republik Indonesia, 2014)

Berdasarkan penelitian-penelitian terdahulu diatas, dapat diidentifikasi beberapa research gap. Alvesson dan Sanberg dalam (Ihwanul Muslim \& Surya Perdhana, 2017) menyebutkan bahwa research gap merupakan permasalahan dalam penelitian yang belum tuntas diteliti atau penelitian yang belum pernah dilakukan sebelumnya. Research gap menjadi 
keunikan dalam penelitian karena berbeda dengan penelitian lain. Research gap penelitian ini menggunakan studi literatur, sedangkan penelitian sebelumnya merupakan penelitian kualitatif dengan pendekatan wawancara dan forum group discussion.

\section{KESIMPULAN}

Berdasarkan hasil dan pembahasan pada bab IV, maka dapat disimpulkan bahwa:

a. Preferensi masyarakat Muslim di Indonesia dalam memilih halal wellness terutama sub sektor fitness \& mind body yaitu aspek sosial dengan pendekatan holistik, fasilitas ruang, tersedianya tempat beribadah, pemisahan gender, kode berpakaian, lokasi yang strategis, instruktur yang kompeten, fasilitas olahraga yang beragam, prinsip dasar kualitas pelayanan yang tinggi seperti kode berpakaian staf dan tamu, cara pembayaran, asuransi dan penggunaan fasilitas perbankan, tersedia makanan halal dan minuman non alkohol serta budaya muslim. Hal ini sesuai dengan ketentuan dari DSN-MUI Nomor 108 Tahun 2016 Tentang Pedoman Penyelenggaraan Pariwisata Berdasarkan Prinsip Syariah. Adanya label halal pada produk jasa fitness \& mind body dapat meningkatkan minat konsumen muslim untuk berolahraga di tempat kebugaran.

b. Penelitian-penelitian sebelumnya mayoritas hanya menggunakan metode penelitian kualitatif dengan objek wanita muslimah saja.

\section{UCAPAN TERIMA KASIH}

Terima kasih kepada tim peneliti prodi Manajemen Universitas Al Azhar Indonesia (UAI) terutama dosen konsentrasi pemasaran dan kewirausahaan yang telah mendukung artikel ini, terima kasih juga kepada Lembaga Penelitian dan Pengabdian Masyarakat (LPPM) UAI yang telah mendanai riset ini dengan skema Stimulus Grant Riset UAI tahun 2020.

\section{REFERENSI}

Bastaman, A. (2019). Exploratory Analysis Of Halal Hotel Services: Based On Practices Of Halal Hotels In Three Countries. Advances in Economics, Business and Management Research, International Conference on Organizational Innovation 100(ICOI-2019), 69-74. Atlantis Press.
Bauty, L. A. (2020). Analysis Of Marketing Strategy Implementation In Gym Sports Especially For Muslims. Islamic Economic, Accounting and Management Journal (TSARWATICA), Vol.1, No.2: 21-25.

Beauchemin, J., Facemire, S., \& McGrath, C. (2015). Enhancing mind-body health in the exercise and fitness industry incorporating a mental skills model. ACSM's Health and Fitness Journal, Vol.19, No.3: 10-16.

Bungin, B. (2008). Penelitian Kualitatif; Komunikasi, Ekonomi, Kebijakan Publik dan Ilmu Sosial Lainnya; Kencana.

Chen, J. s, Prebensen, N., \& Huan, T. . (2008). Anatolia: An International Journal of Tourism and The Mediterranean Tourist Milieu. An International Journal of Tourism and Hospitality Research, Vol.17, No. 1: 37-41.

Henderson, J. C. (2009). Islamic Tourism Reviewed. Tourism Recreation Research, Vol 32, No.2:207-211.

Ihwanul Muslim, M., \& Surya Perdhana, M. (2017). Glass Ceiling: sebuah Studi Literatur. Jurnal Strategi Bisnis. 28 -38.

Kotler, P., \& Keller, K. L. (2006). Manajemen Pemasaran (kesebelas);Indeks Gramedia.

Mohamed, S., Zaidi, A., \& Ahmad, S. Z. (2019). Tone fi thess ladies' studio: market segmentation or market mix ? Emerald Emerging Markets Case Studies, Vol 9, No.1: 1-10.

Muharam, I. N., \& Asutay, M. (2019). Online disclosure practices of halal-friendly hotels. Journal of Islamic Marketing.

Peyman, N., Rezai-rad, M., Tehrani, H., Gholian-aval, M., \& Vahedian-shahroodi, M. (2020). Digital Media-based Health Intervention on the promotion of Women's physical activity: a quasi-experimental study. 2018, 1-8.

Republik Indonesia. (2014). Undang - Undang Republik Indonesia U No. 33 Tahun 2014 tentang Jaminan Produk Halal. Undang - Undang Republik Indonesia.

Robbins, P. S. (2006). Organizational Behaviour; Pretince Hall.

Sobari, N., Kurniati, A., \& Usman, H. (2019). The influence of Islamic attributes and religious commitments toward halal wellness services customer satisfaction and loyalty.Journal of Islamic Marketing, Vol. ahead-of-print No. ahead-of-print. 
Sugiono. (2005). Memahami Penelitian Kualitatif;:Alfabeta.

Summers, J., Hassan, R., Ong, D., Hossain, M., Summers, J., \& Hassan, R. (2018). Australian Muslim women and fi tness choices - myths debunked. Journal of Services Marketing, vol.32, No.5: 605-615.

Vargo, S. L., \& Lusch, R. F. (2012). Evolving to for Logic Marketing. Journal of Marketing, Vol.68, No.1: 1-17.
Wellness Now a \$4.2 Trillion Global Industry - Global Wellness Institute. (n.d.). Retrieved February 9, 2021, from https://globalwellnessinstitute.org/pressroom/press-releases/wellness-now-a-4-2-trillionglobal-industry/ 